\title{
ANALISIS UJI INFUSA BUAH PETAI CINA, DAUN KEJI BELING DAN DAUN TEMPUYUNG SEBAGAI INHIBITOR ENZIM $\alpha$-AMILASE DAN $\alpha$-GLUKOSIDASE
}

\author{
Silvera Devi Sy a, Musyirna Rahmah Nst ${ }^{\mathrm{b}}$, Riryn Novianty ${ }^{a}$ \\ aJurusan Kimia FMIPA Universitas Riau \\ bSekolah Tinggi Farmasi Riau
}

\author{
Corresponding Author: \\ Riryn Novianty \\ rirynnovianty@lecturer.unri. \\ ac.id
}

Received: February 2019

Accepted: March 2019

Published: March 2019

Publishing services provided by Open Journal Systems

CRiryn Novianty et al. This is an open-access article distributed under the terms of the Creative Commons Attribution License, which permits unrestricted use, distribution, and reproduction in any medium, provided the original author and source are credited.

\begin{abstract}
ABSTRAK
Enzim $\alpha$-amilase dan $\alpha$-glukosidase dalam proses pencernaan akan menghidrolisis amilum menjadi glukosa dan apabila glukosa darah melebihi batas normal ( $>140 \mathrm{mg} / \mathrm{dL}$ ), maka seseorang didiagnosa menderita diabetes melitus. Pengobatan diabetes melitus khususnya tipe 2 biasanya diatasi menggunakan obat akarbose yang akan menginhibisi aktivitas $\alpha$-amilase dan $\alpha$-glukosidase. Pada penelitian ini akan dianalisis kemampuan inhibisi infusa dari sampel segar dan kering buah petai cina (Leucaena leucocephala $\mathrm{L}$ de Wit), daun keji beling (Strobilanthes crispus BI) dan daun tempuyung (Sonchus arvensis L.) terhadap ke 2 enzim ini. \% inhibisi infusa terhadap aktivitas enzim $\alpha$-amilase ditentukan menggunakan metode asam 3,5dinitrosalisilat (DNS) sedangkan untuk $\alpha$-glukosidase menggunakan substrat p-nitrofenil- $\alpha$-D-glukopiranosida (p-NPG). Absorbansi hasil reaksi diukur menggunakan microplate reader pada panjang gelombang $530 \mathrm{~nm}$ untuk $\alpha$-amilase dan $410 \mathrm{~nm}$ untuk $\alpha$-glukosidase. Hasil penelitian menunjukkan bahwa \% inhibisi infusa sampel kering lebih baik dibandingkan sampel segar dalam menghambat aktivitas enzim $\alpha$-amilase dengan persentase sebagai berikut: infusa buah petai cina kering $92,54 \pm 1,11 \%$, infusa daun keji beling kering $99,79 \pm 6,92 \%$ dan infusa daun tempuyung kering $87,63 \pm 3,95 \%$, nilai ini tidak berbeda nyata dengan akarbose $93,89 \pm 0,02 \%$. Sedangkan $\%$ inhibisi terhadap aktivitas enzim $\alpha-$ glukosidase dari semua sampel memiliki perbedaan yang nyata dengan akarbose $(\mathrm{P}<0,05)$ dengan nilai inhibisi $97,99 \pm 0,19 \%$. Hasil ini menunjukkan bahwa ketiga tanaman tersebut berpotensi sebagai antidiabetes terutama dalam menginhibisi aktivitas enzim $\alpha$-amilase.
\end{abstract}

Kata kunci: $\alpha$-amilase, $\alpha$-glukosidase, keji beling, petai cina, tempuyung

\section{PENDAHULUAN}

Enzim $\alpha$-amilase secara in vivo menghidrolisis amilum menjadi maltosa baik di mulut maupun di usus halus. Maltosa di usus akan dihidrolisis oleh enzim $\alpha$-glukosidase menjadi glukosa, selanjutnya glukosa diserap oleh darah sehingga akan meningkatkan kadar glukosa darah. Kadar glukosa di dalam darah harus normal yaitu $140 \mathrm{mg} / \mathrm{dL}$, apabila kadar gula darah melebihi $140 \mathrm{mg} / \mathrm{dL}$ maka berisiko terjangkit diabetes ${ }^{[1]}$. Menurut data IDF (International Diabetes Federation) diperkirakan sebanyak 382 juta penduduk dunia mengidap diabetes pada tahun 2013 dan jumlah ini akan terus meningkat mencapai 592 juta pada tahun 2035. Indonesia sendiri menempati posisi ketujuh jumlah penderita diabetes terbanyak, yaitu diperkirakan sebesar 8,5 juta ${ }^{[2]}$. 
Berdasarkan hasil Riset Kesehatan Dasar/Riskesdas 2013, terdapat sekitar 41.071 penduduk usia di atas 15 tahun yang menderita penyakit diabetes di Provinsi Riau.

Berdasarkan klasifikasi American Diabetes Association/World Health Organization (ADA/WHO) diabetes melitus dibagi atas dua tipe yaitu tipe 1 (DM 1) atau insulin dependent diabetes mellitus dan tipe 2 (DM 2) atau noninsulin dependent diabetes. Pada tipe I sel pankreas yang menghasilkan insulin mengalami kerusakan akibatnya sel-sel $\beta$ tidak dapat mensekresi insulin, penderita tipe I ini selalu tergantung pada insulin. Pada tipe II, selsel $\beta$ pankreas tidak rusak dan masih bisa mensekresi insulin, biasanya disebabkan oleh pola makan yang berlebihan sehingga kadar glukosa darah meningkat [3]. Pengobatan DM II ini dilakukan dengan mengatur pola makan dan berolahraga[ ${ }^{[3]}$ serta mengurangi kadar glukosa darah melalui penghambatan kerja enzim $\alpha$-amilase dan $\alpha$-glukosidase ${ }^{[4]}$.

Obat generik yang beredar sebagai antidiabetes adalah akarbose yang dapat menurunkan kadar glukosa darah setelah makan dan sangat efektif diberikan pada penderita diabetes tipe 2. Efek sampingnya adalah gangguan fungsi hati dan ginjal, terutama pada pasien yang pernah mengalami gangguan tersebut. Karena itu untuk pemakaian jangka lama, obat ini diperlukan pemantauan fungsi hati dan ginjal $[5,6]$.

Pada saat ini paradigma untuk pengobatan adalah back to nature artinya kembali ke pengobatan tradisional. Pemanfaatan tanaman obat sebagai inhibitor aktifitas enzim dapat mengontrol kadar gula dalam darah. Beberapa tanaman yang diduga dapat digunakan sebagai inhibitor adalah keji beling (Strobilanthes cripus BI) [7], petai cina (Leucaena leucocephala (Lam.) de Wit) ${ }^{[8]}$ dan tempuyung (Sonchus arvensis L.) [3]. Berdasarkan studi literatur tanaman tersebut mengandung metabolit sekunder dan secara empiris telah dimanfaatkan sebagai obat herbal di masyarakat. Untuk itu perlu dilakukan uji daya inhibisi ekstrak etanol dan infusa dari daun keji beling, buah petai cina dan tempuyung secara in vitro terhadap enzim $\alpha$ amilase dan $\alpha$-glukosidase. Pelarut etanol digunakan karena merupakan pelarut universal yang mampu mengekstraksi hampir semua kandungan kimia alam yang memiliki bobot molekul rendah, tidak toksik, ekonomis serta mudah menguap, sedangkan untuk pemilihan pelarut air karena mengikuti cara masyarakat pada umumnya dalam mengolah tanaman herbal sebagai obat alternatif.

\section{METODE PENELITIAN}

Alat dan bahan yang digunakan dalam penelitian ini adalah neraca analitik, penangas air, rotary evaporator, pipet mikro, panci infusa, kertas saring, kain flanel, microplate reader 96 wells, spektrofotometer UV-Vis, dan alat-alat gelas yang biasa digunakan di Laboratorium, buah petai cina, daun keji beling, daun tempuyung, aqua DM, amilum, enzim $\alpha$ amilase, tablet akarbose (glucobay $\left.{ }^{\circledR}\right)$, enzim $\alpha$ glukosidase, asam 3,5-dinitrosalisilat (DNS), pnitrofenil- $\alpha$-D-glukopiranosida (p-NPG) .

\section{A. Preparasi sampel}

Sampel daun keji beling dan petai cina diperoleh dari Kampus FMIPA UR Pekanbaru dan daun tempuyung diperoleh dari dari Wilayah Kelok Sembilan Payakumbuh Sumatera Barat. Sampel petai cina diambil bagian buahnya, keji beling dan tempuyung diambil bagian daunnya. Identifikasi ketiga sampel dilakukan di Lab Botani FMIPA UR. Setelah masing-masing sampel disortasi kemudian dirajang, ditimbang dan dikeringkan menggunakan oven pada suhu $30-40^{\circ} \mathrm{C}$ hingga beratnya konstan dan dihitung kadar air dan rendemennya.

\section{B. Uji Fitokimia}

Uji fitokimia dilakukan terhadap sampel kering maupun segar yang terdiri atas identifikasi alkaloid, flavonoid, fenolik, saponin, terpenoid dan steroid.

\section{Pembuatan Infusa}

Setelah sampel kering kemudian ditimbang beratnya equivalen dengan $50 \%$ berat sampel segar. Selanjutnya diekstraksi menggunakan pelarut air sebanyak $100 \mathrm{~mL}$ sehingga didapat 
konsentrasi ekstrak equivalen dengan 50\% sampel segar. Ekstraksi dilakukan dengan cara perebusan dalam panci infusa pada suhu $90^{\circ} \mathrm{C}$ selama 15 menit. Air rebusan dari masingmasing sampel didiamkan, disaring dan filtrat (infusa) disimpan untuk pengujian inhibisi enzim $\alpha$-amilase dan $\alpha$-glukosidase.

\section{Uji Inhibisi sampel terhadap aktivitas enzim $\alpha$-amilase}

Uji inhibisi infusa terhadap aktivitas enzim $\alpha$ amilase secara in vitro dilakukan dengan cara menghidrolisis substrat amilum menjadi maltosa. Maltosa akan bereaksi dengan DNS membentuk warna dari kuning menjadi orange yang diukur absorbansinya menggunakan microplate reader 96 well pada panjang gelombang $530 \mathrm{~nm}$ (Tabel 1).

\section{E. Uji Inhibisi sampel terhadap aktivitas enzim $\alpha$-glukosidase}

Pengujian inhibisi infusa terhadap aktivitas enzim $\alpha$-glukosidase menggunakan substrat p-nitrofenil- $\alpha$-D-glukopiranosida. Warna kuning dari senyawa p-nitrofenil yang terbentuk diukur absorbansinya menggunakan microplate reader 96 well pada panjang gelombang $410 \mathrm{~nm}$ (Tabel 2).

Tabel 1. Sistem reaksi uji inhibisi enzim $\alpha$-amilase

\begin{tabular}{|c|c|c|c|c|c|c|}
\hline \multirow{2}{*}{ Reagen } & \multicolumn{6}{|c|}{ Volume $(\mu \mathrm{l})$} \\
\hline & $\mathbf{B}_{1}$ & $\mathbf{B}_{0}$ & $\mathrm{~S}_{1}$ & $S_{0}$ & $\mathbf{A}_{1}$ & $\mathbf{A}_{0}$ \\
\hline Sampel & - & - & 150 & 150 & - & - \\
\hline Akarbose & - & - & - & - & 150 & 150 \\
\hline Aqua DM & 400 & 800 & 250 & 650 & 250 & 650 \\
\hline Enzim & 400 & - & 400 & - & 400 & - \\
\hline \multicolumn{7}{|c|}{ Inkubasi 30 menit, suhu $37^{\circ} \mathrm{C}$} \\
\hline Substrat & 50 & 50 & 50 & 50 & 50 & 50 \\
\hline \multicolumn{7}{|c|}{ Inkubasi 40 menit, suhu $37^{\circ} \mathrm{C}$} \\
\hline DNS & 25 & 25 & 25 & 25 & 25 & 25 \\
\hline
\end{tabular}

Keterangan:

B1: Blanko $(\mu \mathrm{L})$

$S_{1}$ : Sampel $(\mu \mathrm{L})$

A1: Akarbose $(\mu \mathrm{L})$

$\mathrm{B}_{0}$ : Kontrol blanko( $\left.\mu \mathrm{L}\right)$

So: Kontrol sampel $(\mu \mathrm{L})$

Ao: Kontrol akarbose $(\mu \mathrm{L})$

Tabel 2. Sistem reaksi uji inhibisi enzim $\alpha$-glukosidase

\begin{tabular}{|c|c|c|c|c|c|c|}
\hline \multirow{2}{*}{ Reagen } & \multicolumn{6}{|c|}{ Volume $(\mu \mathrm{l})$} \\
\hline & $S_{1}$ & $S_{0}$ & $\mathbf{B}_{1}$ & $\mathbf{B}_{0}$ & $\mathbf{A}_{1}$ & $\mathbf{A}_{0}$ \\
\hline Sampel & 10 & 10 & - & - & - & - \\
\hline Akarbose & - & - & - & - & 10 & 10 \\
\hline Aquades & - & - & 10 & 10 & - & - \\
\hline Buffer posfat & 50 & 75 & 50 & 75 & 50 & 75 \\
\hline Enzim & 25 & - & 25 & - & 25 & - \\
\hline \multicolumn{7}{|c|}{ Inkubasi 10 menit, suhu $37^{\circ} \mathrm{C}$} \\
\hline Substrat & 25 & 25 & 25 & 25 & 25 & 25 \\
\hline \multicolumn{7}{|c|}{ Inkubasi 30 menit, suhu $37^{\circ} \mathrm{C}$} \\
\hline $\mathrm{Na}_{2} \mathrm{CO}_{3}$ & 100 & 100 & 100 & 100 & 100 & 100 \\
\hline
\end{tabular}


Tabel 3. Hasil identifikasi sampel

\begin{tabular}{llll}
\hline \multicolumn{1}{c}{ Klasifikasi } & \multicolumn{1}{c}{ Sampel 1 } & \multicolumn{1}{c}{ Sampel 2 } & \multicolumn{1}{c}{ Sampel 3 } \\
\hline Kingdom & Plantae & Plantae & Plantae \\
Divisi & Magnoliophyta & Magnoliophyta & Magnoliophyta \\
Kelas & Magnoliopsida & Magnoliopsida & Magnoliopsida \\
Bangsa & Fabales & Loranthales & Asterales \\
Suku & Fabaceae & Acanthaceae & Asteraceae \\
Marga & Leucaena & Strobilanthes & Sonshus \\
Spesies & Leucaena leucocephala & Strobilanthes crispus BI & Sonshus arvensisL. \\
Nama Daerah & (Lam.) de Wit & Keji Beling & Tempuyung \\
& PetaiCina & & \\
Gambar & & &
\end{tabular}

\section{F. Analisis data}

Data hasil penelitian dianalisis dengan menentukan persen inhibisi enzim $\alpha$-amilase dan $\alpha$-glukosidase dengan menggunakan rumus. Hasil persen inhibisi yang didapat diuji menggunakan one-way analysis of variance (ANOVA) dan Duncan multiple test pada signifkansi 0,05 $(P<0,05)$.

$$
\% \text { inhibisi }=\frac{(\mathrm{B} 1-\mathrm{B} 0)-(\mathrm{S} 1-\mathrm{S} 0)}{\mathrm{B} 1-\mathrm{B} 0} \mathrm{X} 100 \%
$$

Keterangan :

$\mathrm{S}_{1}=$ absorbansi sampel

$\mathrm{S}_{0}=$ absorbansi kontrol sampel

$\mathrm{B}_{1}=$ absorbansi blanko

$\mathrm{B}_{0}=$ absorbansi kontrol blanko

\section{HASIL DAN DISKUSI}

Hasil indentifikasi tanaman yang dijadikan sampel dalam penelitian dapat dilihat pada Tabel 3. Dari hasil identifikasi tersebut dapat dipastikan bahwa spesies dari masing-masing tanaman sebagai sampel untuk inhibitor enzim $\alpha$-amilase dan $\alpha$-glukosidase adalah Leucaena leucocephala (Lam.) de Wit (petai cina), Strobilanthes crispus BI (keji beling) dan Sonchus arvensis $\mathrm{L}$ (tempuyung).

\section{Uji fitokimia}

Uji fitokimia dilakukan untuk mengetahui kandungan metabolit sekunder dari ketiga sampel, baik sampel segar maupun sampel kering. Identifikasi senyawa kimia dilakukan terhadap senyawa golongan alkaloid, flavonoid, fenolik, saponin, terpenoid dan steroid yang dapat dilihat pada Tabel 4. Dari data di atas diperoleh bahwa tidak satupun sampel yang positif mengandung alkaloid, baik pada sampel segar maupun sampel kering. Hal ini dapat disebabkan karena pengambilan sampel di daerah yang berbeda, sehingga kandungan senyawa metabolit sekundernya pun berbeda. Uji flavonoid diperoleh bahwa buah petai cina dan daun tempuyung positif mengandung flavonoid, hal ini sesuai dengan literatur yang menyatakan bahwa daun tempuyung mengandung flavonoid [10]. Flavonoid hanya terkandung pada sampel segar saja, hal ini diduga karena adanya senyawa yang hilang atau rusak pada proses pengeringan. Uji fenolik diperoleh bahwa buah petai cina segar positif mengandung fenolik sedangkan sampel keringnya tidak. Hal ini juga diduga karena adanya senyawa yang hilang atau rusak pada proses pengeringan. 
Tabel 4. Data uji fitokimia

\begin{tabular}{|c|c|c|c|c|c|c|c|c|}
\hline No. & Sampel Tanam & & Alkaloid & Flavonoid & Fenolik & Saponin & Terpenoid & Steroid \\
\hline \multirow{2}{*}{1} & \multirow{2}{*}{$\begin{array}{l}\text { Buah Petai } \\
\text { Cina }\end{array}$} & $S$ & - & + & + & + & - & - \\
\hline & & $\mathrm{K}$ & - & - & - & + & - & + \\
\hline \multirow{2}{*}{2} & \multirow{2}{*}{ Daun Keji Belin- } & $S$ & - & - & - & - & - & + \\
\hline & & $\mathrm{K}$ & - & - & - & - & - & + \\
\hline \multirow{2}{*}{3} & \multirow{2}{*}{$\begin{array}{l}\text { Daun } \\
\text { Tempuyung }\end{array}$} & $\mathrm{S}$ & - & + & - & - & - & + \\
\hline & & K & - & - & + & - & - & - \\
\hline Kete & angan: & $\begin{array}{l}\text { : Sa } \\
: \mathrm{Sa}\end{array}$ & $\begin{array}{l}\text { el segar } \\
\text { el kering }(-\end{array}$ & $\begin{array}{l}\text { : terd } \\
: \text { tidal }\end{array}$ & $\begin{array}{l}\text { ksi } \\
\text { erdeteksi }\end{array}$ & & & \\
\hline
\end{tabular}

Tabel 5. Persen (\%) kadar air sampel

\begin{tabular}{clcc}
\hline No. & \multicolumn{1}{c}{ Sampel Tanaman } & Kadar air $(\%)$ & $\begin{array}{c}\text { rendemen } \\
(\%)\end{array}$ \\
\hline 1. & Buah Petai Cina & 36,17 & 63,83 \\
2. & Daun Keji Beling & 33,33 & 66,67 \\
3. & Daun Tempuyung & 17,39 & 92,61 \\
\hline
\end{tabular}

Sifat senyawa fenol mudah teroksidasi dan sensitif terhadap panas, sehingga dengan adanya proses pemanasan pada sampel kering dapat menurunkan kandungan senyawa fenol [11]. Uji saponin memberikan hasil yang positif untuk sampel petai cina segar dan kering, sedangkan hasil negatif diperoleh untuk keji beling dan tempuyung. Hasil ini sesuai dengan literatur yang menyatakan bahwa petai cina positif mengandung saponin [12]. Untuk uji terpenoid ketiga sampel ternyata menunjukkan hasil yang negatif. Uji steroid positif pada daun keji beling segar dan kering, buah petai cina kering dan daun tempuyung segar.

\section{Persen (\%) kadar air sampel}

Sampel tanaman yang telah dikeringkan menggunakan oven pada suhu $30-40^{\circ} \mathrm{C}$ ditentukan \% kadar airnya dengan menimbang sampel sebelum dan sesudah dikeringkan sampai beratnya konstan, hasil perhitungan \% kadar air dapat dilihat pada Tabel 5.

Pengeringan sampel tanaman ini dilakukan dengan oven pada suhu $30-40{ }^{\circ} \mathrm{C}$, tujuannya untuk meningkatkan kualitas penyimpanan, mencegah jamur, bakteri dan perubahan kimia. Suhu yang digunakan tidak boleh terlalu tinggi karena dapat merusak bagian tanaman tersebut dan senyawa kimia yang terkandung di dalamnya ${ }^{[9]}$. Persentase kadar air dan rendemen dapat ditentukan melalui proses pengeringan ini. Pada Tabel 5 dapat dilihat bahwa buah petai cina memiliki kadar air dengan persentase terbesar sedangkan rendemen terbesar terdapat pada daun tempuyung. Persentase kadar air dan rendemen pada masing-masing tanaman penting untuk diketahui agar diperoleh perbandingan berat sampel segar dengan berat sampel kering.

Selanjutnya sampel kering ini diekstraksi dengan air (infusa). Teknik infusa ini dipilih berdasarkan pengolahan tanaman-tanaman obat yang sering digunakan oleh banyak masyarakat yaitu perebusan menggunakan air. Air akan lebih cenderung menarik senyawa yang bersifat sangat polar yang kemungkinan tidak bisa tertarik oleh etanol karena etanol merupakan pelarut yang universal. Konsentrasi akhir dari infusa adalah equivalen dengan konsentrasi $50 \%$ sampel segar, pemilihan konsentrasi tersebut berdasarkan buku panduan penanganan simplisia Farmakope Indonesia. 
Tabel 6. Daya inhibisi dari masing-masing infusa sampel kering danakarbose terhadap enzim $\alpha$ amilase dan $\alpha$-glukosidase (Duncan multiple test)

\begin{tabular}{|l|c|c|}
\hline \multirow{2}{*}{ Infusa dari sampel kering } & \multicolumn{2}{c|}{ \% inhibisi } \\
\cline { 2 - 3 } & $\boldsymbol{\alpha}$ - amilase & $\boldsymbol{\alpha}$ - glukosidase \\
\hline Buah Petai Cina & $92,54 \pm 1,11^{\mathrm{a}}$ & $-54,80 \pm 0,00^{\mathrm{d}}$ \\
\hline Daun keji beling & $99,79 \pm 6,92^{\mathrm{a}}$ & $26,44+1,13 \mathrm{c}$ \\
\hline Daun tempuyung & $87,63 \pm 3,95^{\mathrm{a}}$ & $35,20 \pm 1,87^{\mathrm{b}}$ \\
\hline Akarbose & $93,89 \pm 0,02^{\mathrm{a}}$ & $97.99 \pm 0,19^{\mathrm{a}}$ \\
\hline
\end{tabular}

Keterangan :Nilai \% inhibisi dengan kode sama pada kolom yang sama adalah tidak berbeda nyata $(\mathrm{P}>0,05)$

Uji inhibisi enzim $\alpha$-amilase dan $\alpha$ glukosidase secara in-vitro

Kemampuan infusa dari sampel kering lebih baik jika dibandingkan dengan sampel segar menggunakan kontrol positif akarbose menginhibisi enzim $\alpha$-amilase dan $\alpha$ glukosidase secara in-vitro serta uji statistik (Duncan multiple test $\mathrm{P}<0,05$ ) dapat dilihat pada Tabel 6.

Berdasarkan uji Duncan $(\mathrm{P}<0,05), \%$ inhibisi dari infusa ketiga tanaman terhadap $\alpha$-amilase ternyata tidak berbeda nyata dengan akarbose. Hal ini menunjukkan bahwa infusa ke 3 tanaman ini berpotensi sebagai penghambat enzim $\alpha$-amilase. Diantara ketiga tanaman tersebut yang paling potensial adalah infusa sampel kering daun keji beling karena mengandung senyawa aktif steroid yang diduga sebagai agen antidiabetes. Penelitian lainnya melaporkan bahwa ekstrak etil asetat daun pandan wangi memiliki aktivitas antidiabetes dengan aktivitas penghambatan (IC50) sebesar 94,23 ppm. Adapun senyawa yang diduga memiliki aktivitas antidiabetes pada penelitian tersebut adalah steroid [13]. Pada uji fitokimia petai cina mengandung metabolit saponin dan steroid yang diduga mampu menginhibisi enzim $\alpha$-amilase, karena senyawa saponin diketahui memiliki aktivitas hiperglikemik dan saponin dapat merangsang pelepasan insulin [14]. Daun tempuyung mengandung fenolik yang diketahui memiliki berbagai efek farmakologi dan merupakan senyawa aktif yang telah diteliti memiliki aktivitas antidiabetes [15].
Dapat dilihat bahwa kemampuan inhibisi infusa dari ketiga sampel terhadap enzim $\alpha$-glukosidase relatif sangat kecil dengan \% inhibisi berbeda nyata dengan akarbose. Khusus untuk infusa buah petai cina mempunyai nilai inhibisi negatif yang menandakan bahwa infusa tersebut bertindak sebagai aktivator enzim $\alpha$-glukosidase karena nilai absorbansi $[($ S1-S0) $>$ (B1-B0)] sehingga mampu menaikkan aktivitas enzim untuk merubah substrat menjadi produk. Hal yang sama juga terjadi pada penelitian sebelumnya yang mendapatkan nilai inhibisi dari ekstrak kulit dan daging buah salak terhadap enzim $\alpha$ glukosidase mempunyai nilai di bawah $0 \%{ }^{[16]}$.

\section{KESIMPULAN}

Dari hasil penelitian dapat disimpulkan bahwa $\%$ inhibisi masing-masing infusa sampel terhadap aktivitas enzim $\alpha$-amilase adalah sebagai berikut: infusa buah petai cina kering $92,54 \% \pm 1,11$, infusa daun keji beling kering $99,79 \% \pm 6,92$ dan infusa daun tempuyung kering $87,63 \% \pm 3,95$. Nilai ini tidak berbeda nyata dengan akarbose $(\mathrm{P}>0,05)$ dengan nilai inhibisi $93,89 \% \pm 0,02$. Sedangkan persen $(\%)$ inhibisi terhadap aktivitas enzim $\alpha$-glukosidase dari semua sampel memiliki perbedaan yang nyata dengan akarbose $(\mathrm{P}<0,05)$ dengan nilai inhibisi $97,99 \pm 0,19 \%$. Hasil ini menunjukkan bahwa ketiga tanaman tersebut berpotensi sebagai antidiabetes terutama dalam menginhibisi aktivitas enzim $\alpha$-amilase karena mengandung senyawa aktif steroid, saponin dan fenolik. 


\section{UCAPAN TERIMA KASIH}

Penulis mengucapkan terima kasih kepada DIKTI yang telah mendanai penelitian ini melalui dana Hibah Bersaing dengan nomor kontrak 574/UN 19.5.1.3/LT/2015.

\section{DAFTAR PUSTAKA}

1. Sutanto, T., Diabetes: Deteksi, Pencegahan, Pengobatan, Yogyakarta: Buku Pintar (2013)

2. International Diabetes Federation (IDF), Diabetes Atlas, 6 ${ }^{\text {th }}$ ed: p.11-13 (2013).

3. Wijayakusuma, H., Bebas Diabetes Mellitus Ala Hembing. Puspa Swara, Jakarta (2004).

4. Badawi, H. Melawan dan Mencegah Diabetes.Araska, Yogyakarta (2009)

5. Bharti, S. K., Krishnan, S. \& Kumar, A., Phytotherapy for diabetes mellitus: back to nature. Minerva Endocrinol. 41(1): 143-146 (2016)

6. Wang, H., Ni, Y., Yang, S., Li, H., Li, X. \& Feng, B., The effects of gliclazide, metformin, and acarbose on body composition in patients with newly diagnosed type 2 diabetes mellitus. Curr. Ther. Res. Clin. Exp., 75: 88-92 (2013)

7. Nonci, F. Y., Leboe, D.W. \& Armaila. Uji Aktivitas Ekstrak Etanol Daun Keji Beling (Strobilanthes crispus Linn) Terhadap Penurunan Kadar Glukosa Darah Pada Mencit Jantan (Mus musculus). JF FIK UINAM, 4(1): (2016)

8. Rachmatiah, T., Nurvita, H. \& Triana, R. Potensi Antidiabetes Pada Tumbuhan Petai Cina (Leucaena leucocephala (Lam). De Wit). Sainstech., 25(1): (2015)

9. Yuliastuti, W. Uji Aktivitas penghambatan enzim $\alpha$-glukosidase dan penapisan fitokimia dari beberapa tanaman famili apocynaceae dan rubiaceae. Skripsi. FMIPA UI, Depok (2011).

10. Ramadhani, R. A., Kusrini, D. \& Fachriyah, E., Isolasi, identifikasi dan uji antioksidan senyawa flavonoid dari ekstrak etil asetat daun tempuyung (Sonchus arvensis L.). Chem. Info., 1(1): 247-255 (2013).

11. Luximon-Ramma, A., Bahorun, T., Soobrattee, M. A. \& Aruoma, O. I., Antioxidant activities of phenolic, proanthocyanidin, and flavonoid components in extract of cassia fistula. $J$. Agric. Food Chem., 50(18): 5042-5047 (2002).

12. Abriyani, E., Identifikasi Metabolit Sekunder Ekstrak Etanol Daun Tanaman Petai Cina adalah Leucaena leucocephala (Lam.) de Wit. Pharma Explore, 3(2): 203208 (2018)

13. Sukandar, D., Hermanto, S. \& Al mabrur, I., Aktivitas Senyawa Antidiabetes dari Ekstrak Etil Asetat Daun Pandan Wangi (Pandanus amaryllifolius Roxb.). Jurnal Kimia Valensi, 1(6): 269-273 (2010)

14. Arif, T., Gahlaut, A., Sharma, B., Dabur, R. \& Kumar, V., Anti-diabetic agents from medicinal plants: a review. Chemical Biology Letters 1(1): 1-13 (2013)

15. Kaempe, H., Suryanto, E. \& Kawengian, S., Potensi Ekstrak Fenolik Buah Pisang Goroho (Musa Spp.) Terhadap Gula Darah Tikus Putih (Rattus norvegicus). Chem. Prog., 6(1): 6-10 (2013)

16. Sahputra, R. M., Potensi ekstrak kulit dan daging buah salak sebagai antidiabetes. Skripsi. Bogor: FMIPA, IPB (2008). 